\title{
Front Matter: Volume 11929
}

, "Front Matter: Volume 11929," Proc. SPIE 11929, International Workshop on Automation, Control, and Communication Engineering (IWACCE 2021), 1192901 (4 October 2021); doi: 10.1117/12.2616339

SPIE Event: International Workshop on Automation, Control, and Communication Engineering, 2021, Virtual Event, China 


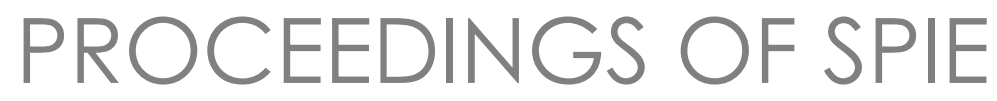

\section{International Workshop on Automation, Control, and Communication Engineering (IWACCE 2021)}

Qi Huang

Editor

7-9 August 2021

Virtual Event

Organized and Sponsored by

Association for Science and Engineering

Published by

SPIE

Volume 11929 
The papers in this volume were part of the technical conference cited on the cover and title page. Papers were selected and subject to review by the editors and conference program committee. Some conference presentations may not be available for publication. Additional papers and presentation recordings may be available online in the SPIE Digital Library at SPIEDigitalLibrary.org.

The papers reflect the work and thoughts of the authors and are published herein as submitted. The publisher is not responsible for the validity of the information or for any outcomes resulting from reliance thereon.

Please use the following format to cite material from these proceedings:

Author(s), "Title of Paper," in International Workshop on Automation, Control, and Communication Engineering (IWACCE 2021), edited by Qi Huang, Proc. of SPIE 11929, Seven-digit Article CID Number (DD/MM/YYYY); (DOI URL).

ISSN: 0277-786X

ISSN: 1996-756X (electronic)

ISBN: 9781510647268

ISBN: 9781510647275 (electronic)

Published by

SPIE

P.O. Box 10, Bellingham, Washington 98227-0010 USA

Telephone +1 3606763290 (Pacific Time)

SPIE.org

Copyright @ 2021 Society of Photo-Optical Instrumentation Engineers (SPIE).

Copying of material in this book for internal or personal use, or for the internal or personal use of specific clients, beyond the fair use provisions granted by the U.S. Copyright Law is authorized by SPIE subject to payment of fees. To obtain permission to use and share articles in this volume, visit Copyright Clearance Center at copyright.com. Other copying for republication, resale, advertising or promotion, or any form of systematic or multiple reproduction of any material in this book is prohibited except with permission in writing from the publisher.

Printed in the United States of America by Curran Associates, Inc., under license from SPIE.

Publication of record for individual papers is online in the SPIE Digital Library.

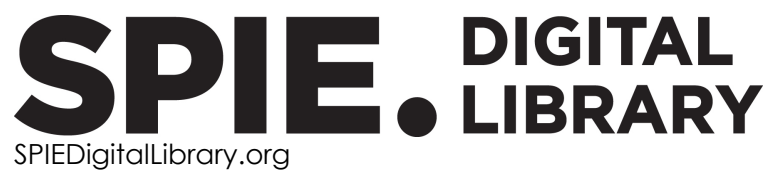

Paper Numbering: A unique citation identifier (CID) number is assigned to each article in the Proceedings of SPIE at the time of publication. Utilization of CIDs allows articles to be fully citable as soon as they are published online, and connects the same identifier to all online and print versions of the publication. SPIE uses a seven-digit CID article numbering system structured as follows:

- The first five digits correspond to the SPIE volume number.

- The last two digits indicate publication order within the volume using a Base 36 numbering system employing both numerals and letters. These two-number sets start with 00, 01, 02, 03, 04, 05, 06, 07, 08, 09, 0A, OB ... 0Z, followed by 10-1Z, 20-2Z, etc. The CID Number appears on each page of the manuscript. 


\section{Contents}

INTERNATIONAL WORKSHOP ON AUTOMATION, CONTROL, AND COMMUNICATION ENGINEERING (IWACCE 2021)

1192902 Fault diagnosis method of centrifugal pump based on PARAFAC-SVM [11929-3]

1192903 Leader-follower irrigation system management with Shapley value [1 1929-4]

1192904 A task offloading approach based on opportunistic prediction in mobile ad-hoc network [11929-5]

1192905 Software reliability and security test model of intelligent electric meters [1 1929-6]

1192906 Hyperspectral moving target detection algorithm based on multi-scale fusion [11929-8]

1192907 SA-LIFT: a similar area learning invariant feature transform network framework [1 1929-9]

1192908 Fault detection of microwave source in high-power microwave heating system based on wavelet analysis [11929-13]

1192909 Design of a smart hotel RCU system with re-configurable control logic [1 1929-14]

11929 OA A monitoring signal denoising algorithm of eddy current for outer casing pipe of double-layer pipe [1 1929-15]

$11929 \mathrm{OB} \quad$ A method for on-line monitoring and fault positioning of abnormality in multi-epitope voltagewithstand test device [11929-16] 
Proc. of SPIE Vol. 11929 1192901-4 Downloaded From: https://www.spiedigitallibrary.org/conference-proceedings-of-spie on 26 Apr 2023
Terms of Use: https://www.spiedigitallibrary.org/terms-of-use 